\title{
Integration Into the Global Mainstream of Engineering Education Based on the Digital Paradigm
}

\author{
Natalya Pugacheva ${ }^{1},{ }^{*}$ Tatiana Dymolazova ${ }^{1}$, Marseille Hakimullin ${ }^{1}$, Oleg \\ Zakharov $^{2}$, Tatyana Kirillova ${ }^{3}$, Anastasia Luchinina ${ }^{4}$ \\ ${ }^{1}$ Kazan State University of Architecture and Engineering, Russia \\ ${ }^{2}$ Kazan National Research Technical University named after Tupolev-KAI (KNITU-KAI), Russia \\ ${ }^{3}$ Research Institute of the Federal Penitentiary Service of Russia, Russia \\ ${ }^{4}$ Vyatka state University, Russia \\ *Email: natalya-pugacheva@yandex.ru
}

\begin{abstract}
The economy digitalization has demanded the training of specialists with competencies for the development and implementation of digital technologies. The purpose of the study is to characterize a virtual workshop for training a process engineer. The methodological basis of the study was a digital paradigm that promotes the introduction of digital content adapted to modern requirements and associated with information bases of a restricted professional profile. The main results of the study are to determine the essence and content of the virtual workshop of mechanical assembly production, to clarify the criteria for the effectiveness of its implementation in the teaching process. The essence of the virtual workshop as a digital educational resource is aimed at developing professional skills of the 21 st century; the content presents a complex multi-level menu. Efficiency criteria (digital, integrative, competence, adequate, productive ones) are determined by the didactic functions of the virtual shop. Research constraints constitute a random selection of respondents. The didactic functions of the virtual workshop (interactive, transdisciplinary, competence, organizational, evaluative ones) reflect the practical significance. The social significance lies in the introduction of digital content into the educational process that imitates professional activities. The originality of the study lies in substantiating the engineering education integration into the world mainstream based on the digital paradigm.
\end{abstract}

Keywords: Digital paradigm, Training of process engineers, Digital educational resources, Mainstream, engineering education, Professional skills of the 21 st century.

\section{INTRODUCTION}

The economy digitalization, the introduction of new generation digital educational resources position the engineering education mainstream based on the digital paradigm as the basis for the convergence of universities. The study of Ricardo-Barreto et al. notes as follows: "The inexorable growth of ICT and the convergence of networks have produced great changes in human culture, and particularly in the educational environment. As a result, the development of appropriate technological competencies and the study of the trends of ICT use to meet this requirement become necessary" [1, p.395]. Mainstream is a scientific field that combines research traditions and recognized modern concepts with a scientific and pedagogical community and academic journals. Modern technical universities train specialists who are able to adapt to information flows, possessing the transdisciplinary competencies of the 21 st century, ready to support an engineering product throughout the entire cycle (Conceive-Design-Implement-Operate). For this, smart technologies are used, electronic portfolios and personal electronic offices are being introduced as innovative tools for engineering education [2]. The article of Terentyeva et al. highlights the following: "Digital educational resources allow: 1) to develop educational programs to develop professional skills for the 21 st century; 2 ) to create training platforms to adapt 
virtual reality technologies to the training process" [3, p.82].

The problem of the engineering education integration based on the digital paradigm attracts a lot of attention from scientists. Two approaches to solving this problem can be stood out. The first approach is pedagogical. Within the framework of this approach, digital educational resources, interactive teaching methods, multimedia training courses and electronic textbooks are being developed, video conferences are held to provide the organization with a digital educational environment $[4,5,6]$. As McDougall puts it, digitalization "can cultivate young peoples' literacies and transform how we think about sites of education" [7, p.264].

The second approach is technological. Within the framework of this approach, digital educational products are created and implemented, focused on the formation of professional competencies of students in accordance with professional standards $[8,9,10]$. "The effective use of emerging technologies demands the training of highly qualified personnel with digital literacy professional skills" [11, p.96]. The conclusions made by the listed authors served as the basis for the study. However, integration into the global mainstream of engineering education requires the definition of a paradigm affiliation.

The study object is the process of integration into the global mainstream of engineering education based on the digital paradigm. The subject of the study is digital resources as a tool for integration into the global mainstream of engineering education. The purpose of the study is to characterize a virtual workshop for training a process engineer.

\section{RESEARCH METHODOLOGY}

The digital paradigm has become the methodological basis of the study. Paradigms are recognized scientific achievements that influence the model of rational scientific activity within a certain time period [12]. The economy digitalization has led to the formation of a digital paradigm for the management of engineering education. The basic concepts of the digital paradigm are as follows: digital didactics, digital technologies, digital textbooks, M-learning, digital educational resources, digital educational environment and digital content. The whole of these concepts determines the subject and scientific novelty of scientific and pedagogical studies. As criteria for evaluating pedagogical studies in the framework of the digital paradigm, it is offered the following: the development of 21 st century skills by students, the formation of digital competencies, the development of digital literacy, the creation of digital technologies, the development of cloud educational systems and the spread of open educational resources. Based on these criteria, the goals and objectives of scientific and pedagogical studies are formulated, their practical significance is determined.

The digital paradigm refers to the value preferences as the integration of traditions and innovations. Traditions ensure the maintenance and dissemination of the best pedagogical experience, continuity in the development of engineering education and a tolerant attitude towards the values of the past; serve as the basis for the creation of new methods, means and teaching tools. Innovations provide a stable relationship between engineering education and scientific and technological progress and constant changes; serve as the basis for the introduction of new methods, means and teaching tools. Integration of traditions and innovations acts as a methodological basis for scientific and pedagogical research, substantiates the necessity, originality of fundamental research and the social, practical significance of applied research [13].

When doing research, theoretical (study of national and international experience of integration into the world mainstream of engineering education based on the digital paradigm) and empirical (observation, polls) methods were used. Experimental work to test the effectiveness of the virtual workshop for the training of a process engineer took place in three stages (ascertaining, forming and control ones). The experimental work involved 300 persons: 50 teachers, 250 students of a technical university. Random samples of teachers and students were drawn up. The sample of teachers included professors (the average age is $\mathbf{5 3}$ years) and associate professors (the average age is 38 years) who conduct training sessions at the Department of Machinery Production Technologies with students majoring in "Design and Technological Support of Machinery Productions." The selection of students included 3-4 year bachelors majoring in this area of training. None of the teachers, students refused to participate in experimental work.

At the ascertaining stage, using a survey, the attitude of teachers and students to digital educational resources was clarified, the effectiveness criteria of introducing a virtual workshop into the learning process were determined. The questionnaire includes two closedended questions with multiple choice of answers (see table 1).

The survey has showed that teachers and students have a stable positive attitude towards digital educational resources. The survey results were discussed in 3 focus groups. Each focus group included 9 people: 7 teachers and 3 students. The focus groups were moderated by teachers. Focus groups found out the effectiveness criteria of the implementation of the virtual workshop in the teaching process (those are digital, integrative, competence, adequate and productive ones). 
Table 1. The results of the survey of teachers (T) and students (S) about the attitude to digital educational resources at the ascertaining stage of experimental work (\%)

\begin{tabular}{|c|c|c|c|}
\hline Content of the question & Answer options & $\mathrm{T}$ & S \\
\hline \multirow{3}{*}{$\begin{array}{l}\text { 1. Why use digital } \\
\text { technologies in the } \\
\text { teaching process? }\end{array}$} & $\begin{array}{l}\text { 1.1. For building professional skills of the } 21 \text { st century and } \\
\text { competitiveness in the labor market }\end{array}$ & 93 & 91 \\
\hline & $\begin{array}{l}\text { For developing readiness to guide engineering products } \\
\text { throughout the entire cycle (Conceive-Design-Implement-Operate) }\end{array}$ & 94 & 86 \\
\hline & 1.3. For being able to step by step observe the process & 97 & 91 \\
\hline \multirow{3}{*}{$\begin{array}{l}\text { 2. What components can } \\
\text { digital educational } \\
\text { resources include? }\end{array}$} & 2.1. 3D Models & 93 & 99 \\
\hline & 2.2. Animation, video & 94 & 98 \\
\hline & 2.3. Interactive products & 97 & 99 \\
\hline
\end{tabular}

At the formative stage, a virtual workshop was created, which made it possible to integrate knowledge, abilities and skills to the level of professional competencies. Students were given training assignments for the development of mechanical assembly production. The virtual workshop was used to visualize production. Based on the results of the assignments, the students prepared interactive reports.

At the control stage, the mastering levels of the educational material with the help of a virtual workshop were revealed.

\section{RESULTS}

The main results are to determine the essence and content of the virtual workshop of mechanical assembly production, clarify the effectiveness criteria of its implementation in the teaching process and identify the levels of mastering the educational material using the virtual workshop.

The essence of the virtual workshop: it is a digital educational resource for developing professional skills of the 21st century and automated assessment by complexity levels. Characteristics of the virtual workshop: cross-platform and multimedia interactive content that simulates professional activities. To create a virtual workshop, 3ds Max and Autodesk Revit software was used [14].

The content of the virtual workshop is a complex multi-level menu. The menu includes constant and dropdown strings. The constant string items correspond to the mechanical assembly production stages: preparation, manufacture of parts, assembly, testing. The drop-down strings correspond to the type of work at each stage.

The effectiveness criteria of introducing a virtual workshop into the learning process are conditioned by the didactic functions that it performs: interactive one (imitation of mechanical assembly production); transdisciplinary one (establishing interdisciplinary relationships); competence one (development of professional skills of the 21st century); organizational one (development of skills and abilities of students' independent work); evaluative one (assessment of learning outcomes).
Table 2 shows the relationship of didactic functions of the virtual workshop with the effectiveness criteria and indicators of implementation in the teaching process.

Criteria and indicators allow identifying the achieved results with the didactic functions of the virtual workshop.

To identify the levels of mastering the educational material using a virtual workshop, students were asked to answer questions and complete tasks that were assessed according to a 5-point system (see table 3).

To identify the levels of mastering the educational material, the value $(\mathrm{Q})$ was determined as the sum $(\mathrm{S})$ for each criterion: $\mathrm{Q}=\mathrm{SD}+\mathrm{SI}+\mathrm{SC}+\mathrm{SA}+\mathrm{SP}$

The values for each criterion were calculated by the formula: $\mathrm{K}=\frac{\sum q_{i}}{n} \mathrm{~S}=\Sigma \mathrm{qi} / \mathrm{n}$, where qi is the average point received for the indicator, $\mathrm{n}$ is the number of criterion indicators.

The value $(\mathrm{Q})$ from 0 to 5 is conventionally considered as a zero level; 6 to 10 is a threshold level; 11 to 15 is a satisfactory level; 16 to 20 is a good level; 21 to 25 is an excellent level. The characteristics of the levels are as follows.

Excellent level - the person knows exactly, is able and masters the educational material. Good level - the person knows and is able to apply educational material but makes minor mistakes in the process of skills implementation. Satisfactory level - the person knows and is able to apply educational material but skills are not mastered, cannot work independently. The threshold level includes fragmentary knowledge, skills, and abilities. Zero one - the person does not know at all, is not able and does not master educational material.

\section{DISCUSSIONS}

Integration into the world mainstream of engineering education based on the digital paradigm leads to the formation of a scientific and pedagogical community that promotes the introduction of digital content into the teaching process coupled with search engines of a restricted professional profile. In the practice of 
Table 2. Didactic functions of the virtual workshop, effectiveness criteria and indicators of implementation in the teaching process

\begin{tabular}{|l|l|l|l|l|}
\hline \multicolumn{1}{|c|}{ functions } & \multicolumn{2}{|c|}{ criteria } & \multicolumn{2}{|c|}{ indicators } \\
\cline { 3 - 5 } & digital & $\begin{array}{l}\text { know the missions } \\
\text { and terminology of } \\
\text { digital production }\end{array}$ & $\begin{array}{l}\text { know how to apply } \\
\text { artificial intelligence in } \\
\text { the process }\end{array}$ & $\begin{array}{l}\text { master technologies } \\
\text { of digital production } \\
\text { transformation }\end{array}$ \\
\hline transdisciplinary & integrative & $\begin{array}{l}\text { master cloud } \\
\text { technologies and } \\
\text { services }\end{array}$ & $\begin{array}{l}\text { know how to use } \\
\text { smart devices }\end{array}$ & $\begin{array}{l}\text { know how to use } \\
\text { process engineer } \\
\text { applications }\end{array}$ \\
\hline $\begin{array}{l}\text { competence- } \\
\text { based }\end{array}$ & $\begin{array}{l}\text { competence- } \\
\text { based }\end{array}$ & $\begin{array}{l}\text { know the stages of } \\
\text { mechanical assembly } \\
\text { production and types } \\
\text { of work }\end{array}$ & $\begin{array}{l}\text { know how to organize } \\
\text { mechanical assembly } \\
\text { production }\end{array}$ & $\begin{array}{l}\text { know how to use } \\
\text { design and } \\
\text { management } \\
\text { methods of } \\
\text { mechanical } \\
\text { assembly } \\
\text { production }\end{array}$ \\
\hline organisational & suitable & $\begin{array}{l}\text { know self- } \\
\text { management and } \\
\text { time management } \\
\text { methods }\end{array}$ & $\begin{array}{l}\text { know how to use self- } \\
\text { management } \\
\text { applications }\end{array}$ & $\begin{array}{l}\text { master teamwork } \\
\text { skills }\end{array}$ \\
\hline evaluative & productive & $\begin{array}{l}\text { know methods of e- } \\
\text { portfolio } \\
\text { collection, self- } \\
\text { assessment and } \\
\text { diagnostics of } \\
\text { professional skills }\end{array}$ & $\begin{array}{l}\text { are able to form } \\
\text { an electronic } \\
\text { portfolio }\end{array}$ & $\begin{array}{l}\text { master self- } \\
\text { assessment and } \\
\text { diagnostics } \\
\text { of professional skills }\end{array}$ \\
& & & & \\
\hline
\end{tabular}

engineering education, digital educational resources have become widespread. The development of a virtual workshop and its introduction into pedagogical practice ensure the interconnection of pedagogical and technological approaches to the problem of integrating the engineering education based on the digital paradigm.
The virtual workshop is an innovative pedagogical tool that allows you to use interactive teaching methods, develop skills in building an electronic portfolio, and form the skills of independent educational work (pedagogical approach). The virtual workshop is a digital educational product focused on the development of

Table 3. Results of answers to questions and assignments on the part of students at the control stage of experimental work (average point)

\begin{tabular}{lc}
\multicolumn{1}{c}{ Criteria and indicators } & average point \\
\hline Digital criterion (D) & 4.7 \\
\hline $\begin{array}{l}\text { 1. Know the missions and terminology of digital production } \\
\text { 2. Know how to apply artificial intelligence in }\end{array}$ & 4.6 \\
\hline
\end{tabular}

\begin{tabular}{lc}
\hline 3. Master technologies of digital production transformation & 4.6 \\
\hline Integrative criterion (I) &
\end{tabular}

\begin{tabular}{ll}
\hline 4. Master cloud technologies and services & 4.8 \\
\hline 5. Know how to use smart devices & 4.6 \\
\hline 6. Know how to use process engineer applications & 4.4 \\
\hline Competence-based criterion (C) & 45 \\
\hline 7. Know the stages of mechanical assembly production and types of work & 4.7 \\
\hline 8. Know how to organize mechanical assembly production & 4.5 \\
\hline 9. Know how to use design and management methods of mechanical assembly production & 4.6 \\
\hline Suitable criterion (A) & 4.9 \\
\hline 10. Know self-management and time management methods & 4.5 \\
\hline 11. Know how to use self-management applications & 4.4 \\
\hline 12.Master teamwork skills & \\
\hline Productive criterion (P) & 5.0 \\
\hline 13. Know methods of e-portfolio collection, self-assessment and diagnostics of professional \\
skills
\end{tabular}


digital literacy and the formation of professional competencies of the 21 st century for process engineers (technological approach). The development and implementation of a virtual workshop in engineering education ensure compliance with modern trends in the economy digitalization and improve the quality of training for process engineers.

\section{CONCLUSION}

Integration into the global mainstream of the engineering education based on the digital paradigm allows developing fundamental research taking into account global trends in science, as well as increasing the effectiveness of applied research aimed at the practical solution of socio-economic problems. The development and implementation of digital educational resources in the context of global challenges and national interests improves the engineering education quality. The virtual workshop as a digital educational resource that imitates professional activities ensures the interconnection of traditions and innovations in the process of engineering education, the training effectiveness of specialists with professional skills of the 21 st century. Efficiency criteria (digital, integrative, competence-based, suitable and productive ones) of the introduction of a virtual workshop into training make it possible to compile a comprehensive description of the results of education and timely adjust its process.

\section{REFERENCES}

[1] C. Ricardo-Barreto, D. Molinares, H. Llinás, J. Santodomíngo, C. Acevedo, P. Rodríguez, C. Navarro, \& S. Villa, Trends in Using ICT Resources by Professors in HEIs (Higher Education Institutions), Journal of Information Technology Education: Research Vol. 19 (2020) 395-425. DOI: https://doi.org/10.28945/4601 (accessed date 10.11.2020)

[2] A. Rea, \& N. Yeates, Open Sourcing the Pedagogy to Activate the Learning Process. International Journal of Information and Communication Technology Education (IJICTE) 16(2) (2020) 1-17. DOI: https://doi.org/10.4018/IJICTE.2020040101 (accessed date 10.11.2020)

[3] I. Terentyeva, A. Lunev, S. Kashina, L. Sadrieva, I. Korolyuk, \& N. Pugacheva, The Virtual Construction Site: Knowledge Management in Virtual Environments, International Journal of Emerging Technologies in Learning (iJET), Vol. 15 No. 13 (2020) 81-95. Retrieved from: https://onlinejournals.org/index.php/ijet/article/view/14655/7423 (accessed date $\underline{10.11 .2020)}$

[4] A. Brilingaite, L. Bukauskas, \& A. Juskeviciene, Competency Assessment in Problem-Based Learning Projects of Information Technologies
Students. Informatics in Education Vol. 17 No. 1 (2018) 21-44. DOI: https://doi.org/10.15388/infedu.2018.02 (accessed date 19.11.2020)

[5] J.R. Jardina, B.S., Chaparro, \& S. Abdinnour, Extending the Task-Technology Fit (TTF) Model to E-Textbook Usage by Students and Instructors, International Journal of Information and Communication Technology Education (IJICTE) 17(1) (2021) 120-137. DOI: https://doi.org/10.4018/IJICTE.2021010108 (accessed date 10.11.2020)

[6] T.A. Sharadgah, \& R.A. Sa'di, Preparedness of Institutions of Higher Education for Assessment in Virtual Learning Environments During the COVID19 Lockdown: Evidence of Bona Fide Challenges and Pragmatic Solutions. Journal of Information Technology Education: Research Vol. 19 (2020) 755-774. DOI: https://doi.org/10.28945/4615 (accessed date 10.11.2020)

[7] J. McDougall, M. Readman, \& P. Wilkinson, The uses of (digital) literacy, Learning, Media and Technology Vol. 43 No. 3 (2018) 263-279. DOI: https://doi.org/10.1080/17439884.2018.1462206 (accessed date 10.11.2020)

[8] R. Ghanbarzadeh, \& A.H. Ghapanchi, Antecedents and Consequences of User Acceptance of ThreeDimensional Virtual Worlds in Higher Education, Journal of Information Technology Education: Research Vol. 19 (2020) 855-889. DOI: https://doi.org/10.28945/4660 (accessed date 10.11.2020)

[9] R. Jain, \& A.K. Singh, Technological Approaches for E-Content Development and Deployment: A Qualitative Analysis From Experts' Perspective. International Journal of Information and Communication Technology Education (IJICTE) 16(3) (2020) 92-112. DOI: https://doi.org/10.4018/IJICTE.2020070107 (accessed date 10.11.2020)

[10] V. Kumar, \& P. Nanda, Social media in higher education: A framework for continuous engagement, International Journal of Information and Communication Technology Education Vol. 15(1) (2019) 109-120. DOI: https://doi.org/10.4018/IJICTE.2019010108 (accessed date 19.11.2020)

[11] N. Pugacheva, T. Kirillova, O. Kirillova, A. Luchinina, I. Korolyuk, \& A. Lunev, Digital paradigm in educational management: The case of construction education based on emerging technologies, International Journal of Emerging Technologies in Learning (iJET) Vol. 15 No. 13 (2020) 96-115. Retrieved from: https://onlinejournals.org/index.php/ijet/article/view/14663/7429 (accessed date $\underline{10.11 .2020)}$ 
[12] T.S. Kuhn, The Structure of Scientific Revolutions. Chicago: The University of Chicago Press, 1970, 222 p. Retrieved from: https://www.lri.fr/ mbl/Stanford/CS477/papers/Ku hn-SSR-2ndEd.pdf (accessed date 10.11.2020)

[13] UNESCO Science Report, Towards 2030 (2015). Retrieved from: https://en.unesco.org/unesco_science_report (accessed date 10.11.2020)

[14] Autodesk https://www.autodesk.ru/ (accessed date 19.11.2020) 